\title{
State of water and thermal properties of zinc and cobalt (II) phosphate solid solution
}

\author{
N.M.Antraptseva, N.V.Solod \\ National University of Life and Environmental Sciences of Ukraine, \\ 17 Heroiv Oborony Str., 03041 Kyiv, Ukraine
}

Received June 19, 2015

\begin{abstract}
It was established that the energy $\mathrm{H}$-bonds and asymmetry of coordinationally connected of water molecules increases with elevation of cobalt content in the structure of $\mathrm{Zn}_{3-\mathrm{x}} \mathrm{Co}_{\mathrm{x}}\left(\mathrm{PO}_{4}\right) 2 \cdot 4 \mathrm{H}_{2} \mathrm{O}(0<x \leq 1.00)$. Thermal properties of phosphate solid solution are investigated. It was found that their thermal stability correlate with the energy state of water molecules and has maximum in the phosphate with composition $\mathrm{Zn}_{2} \mathrm{Co}\left(\mathrm{PO}_{4}\right)_{2} \cdot 4 \mathrm{H}_{2} \mathrm{O}$. It was determined that the temperature ranges of formation and thermal stability of its partial and complete dehydration products at $30-40^{\circ} \mathrm{C}$ higher than in the phosphates, which has less cobalt content. The sequence of thermal solid phase transformations, which accompanying of $\mathrm{Zn}_{3-x} \mathrm{Co}_{x}\left(\mathrm{PO}_{4}\right)_{2} \cdot 4 \mathrm{H}_{2} \mathrm{O}$ dehydration is established.
\end{abstract}

Keywords: phosphate, solid solution, thermal properties, dehydration

Установлено, что энергия Н-связей и асимметрия координационно связанных молекул воды возрастают с увеличением содержания кобальта в структуре $\mathrm{Zn}_{3-}$ ${ }_{\mathrm{x}} \mathrm{Co}_{\mathrm{x}}\left(\mathrm{PO}_{4}\right)_{2} \cdot 4 \mathrm{H}_{2} \mathrm{O}(0<x \leq 1.00)$. Исследованы термические свойства фосфатов твердого раствора, установлено, что их термическая устойчивость коррелирует с энергетическим состоянием молекул воды и максимальна в фосфате состава $\mathrm{Zn}_{2} \mathrm{Co}\left(\mathrm{PO}_{4}\right)_{2} \cdot 4 \mathrm{H}_{2} \mathrm{O}$. Определено, что температурные интервалы образования и термической стабильности продуктов его частичного и полного обезвоживания на $30-40^{\circ} \mathrm{C}$ выше, чем в фосфатах с меньшим содержанием кобальта. Приведена последовательность термических твердофазных превращений, сопровождающих обезвоживания $\mathrm{Zn}_{3-\mathrm{x}} \mathrm{Co}_{\mathrm{x}}\left(\mathrm{PO}_{4}\right)_{2} \cdot 4 \mathrm{H}_{2} \mathrm{O}$.

Стан води та термічні властивості твердого розчину цинк і кобальт(II) фосфатів. Н.М.Антрапцева, Н.В.Солод.

Встановлено, що енергія Н-зв'язків і асиметрія координаційно зв'язаних молекул води зростають зі збільшенням кобальту в структурі $\mathrm{Zn}_{3-\mathrm{x}} \mathrm{Co}_{\mathrm{x}}\left(\mathrm{PO}_{4}\right)_{2} \cdot 4 \mathrm{H}_{2} \mathrm{O}(0<x \leq 1.00)$. Досліджено термічні властивості фосфатів твердого розчину, встановлено, що іх термічна стійкість корелює 3 енергетичним станом молекул води і максимальна у фосфата складу $\mathrm{Zn}_{2} \mathrm{Co}\left(\mathrm{PO}_{4}\right)_{2} \cdot 4 \mathrm{H}_{2} \mathrm{O}$. Визначено, що температурні інтервали утворення $\mathrm{i}$ термічної стабільності продуктів його часткового та повного зневоднення на $30-40^{\circ} \mathrm{C}$ вищі, ніж у фосфатів з меншим вмістом кобальту. Наведено послідовність термічних твердофазних перетворень, що супроводжують зневоднення $\mathrm{Zn}_{3-\mathrm{x}} \mathrm{Co}_{\mathrm{x}}\left(\mathrm{PO}_{4}\right)_{2} \cdot 4 \mathrm{H}_{2} \mathrm{O}$.

\section{Introduction}

Solid solutions of hydrated phosphates of divalent metals, zinc and cobalt particularly, and products of their partial and complete dehydration is widely used as the basis of various inorganic materials: catalysts of the organic synthesis, pigments, thermo- phosphate decorative coverings, corrosion inhibitors, etc. [1-4]. To create on their basis the new materials with a given complex of operational characteristics need to know the composition, temperature ranges of formation and thermal stability of the products of their partial or complete dehydration. The thermal properties of hydrated salts are defined by 
the energy state of water molecules, which belong to their crystal lattice. Therefore the correct choice of conditions of the obtaining of dehydrated phosphate is possible only if to take into consideration the chemistry of dehydration $[2,3]$.

There are investigations devoted to the study of conditions of formation of zinc and cobalt (II) phosphate solid solution with composition $\mathrm{Zn}_{3-x} \mathrm{Co}_{x}\left(\mathrm{PO}_{4}\right)_{2} \cdot 4 \mathrm{H}_{2} \mathrm{O}$ [4, 5], it's chemical nature [6], structural features [4]. Concerning its properties, the authors [4, 7] describe some colorimetric properties of zinc phosphate modified by cobalt, and changes of its color when heated.

Information on the systematic study of water state and thermal properties of zinc and cobalt (II) phosphate solid solution in the literature is absent.

The purpose of the present work is to investigate the state of water and thermal properties of zinc and cobalt(II) phosphate solid solution with general formula $\mathrm{Zn}_{3-x} \mathrm{Co}_{x}\left(\mathrm{PO}_{4}\right)_{2} \cdot 4 \mathrm{H}_{2} \mathrm{O} \quad(0<x \leq 1.00)$, and to determine composition, temperature ranges of formation and thermal stability of the products of partial and complete dehydration.

\section{Experimental}

Solid solution of middle phosphates $\mathrm{Zn}_{3-x} \mathrm{Co}_{x}\left(\mathrm{PO}_{4}\right)_{2} \cdot 4 \mathrm{H}_{2} \mathrm{O} \quad(0<x \leq 1.00)$ and their deuterium analogues obtained by interaction of zinc and cobalt (II) hidrocarbonates with a phosphoric acid solution is similar to the one described in [5]. The saturated solid solution $-\mathrm{Zn}_{2} \mathrm{Co}\left(\mathrm{PO}_{4}\right)_{2} \cdot 4 \mathrm{H}_{2} \mathrm{O}$ and phosphate of composition $\mathrm{Zn}_{2.5} \mathrm{Co}_{0.5}\left(\mathrm{PO}_{4}\right)_{2} \cdot 4 \mathrm{H}_{2} \mathrm{O}$ were used as the main objects of the research.

IR spectra were recorded at $20^{\circ} \mathrm{C}$ and $190^{\circ} \mathrm{C}$ at the range of $400-4000 \mathrm{~cm}^{-1}$ using spectrometer Nexus-470 with Fourier transformation and Omnic software. Samples were prepared by shifting of a fixed batch (0.05 wt. \%) in $\mathrm{KBr}$ matrix. In addition, phosphate slurry in butyl alcohol was used, putting it on a neutral fluorite substrate.

Thermal properties were investigated in the temperature range of $25-900^{\circ} \mathrm{C}$ in dynamic (derivatograph Q-1500 D): platinum crucibles with lid, standard - heated $\mathrm{Al}_{2} \mathrm{O}_{3}$, batch sample - $300 \mathrm{mg}$, heating rate 2.5 degree/min., accuracy of the temperature determining $\pm 5^{\circ} \mathrm{C}$ ) and quasiisotermic (labyrinth crucible, heating rate of $3.0 \mathrm{de}-$ gree/min.) regime of heating. Products of the heat treatment at the temperature corresponding to the thermal effects on DTA curve were identified similarly [8] using complex analysis methods: chemical, X-ray, IR spectroscopy.

\section{Results and discussion}

In the IR spectra of phosphate solid solutions $\mathrm{Zn}_{3-x} \mathrm{Co}_{x}\left(\mathrm{PO}_{4}\right)_{2} \cdot 4 \mathrm{H}_{2} \mathrm{O} \quad 0<x \leq 1.00$ of different composition, and their deuterium analogues, three types of vibrations of water molecules are observed: valence vibrations of $\mathrm{OH}$-groups, deformation and libration vibrations of water molecules. At the room temperature two absorption bands of $v(\mathrm{OH})$ are recorded: one $\delta\left(\mathrm{H}_{2} \mathrm{O}\right)$ and one $\rho\left(\mathrm{H}_{2} \mathrm{O}\right)$; the value of their absorption bands in the spectrum of phosphate $\mathrm{Zn}_{2} \mathrm{Co}\left(\mathrm{PO}_{4}\right)_{2} \cdot 4 \mathrm{H}_{2} \mathrm{O}$ and their attribution is shown in Table 1 . At the low temperatures $\left(-190^{\circ} \mathrm{C}\right)$ multiplicity of the spectra increases and in the $\mathrm{v}(\mathrm{OH})$ vibrations four absorption maxima $(3500,3345,3230$ and $3095 \mathrm{~cm}^{-1}$ ) are observed, in the deformation vibrations their number is two (1635, $\left.1630 \mathrm{~cm}^{-1}\right)$. Intensity of the individual bands slightly increases.

If to consider the vibrations of free water molecules (it symmetry $C_{2 v}$ ), one can present a picture of splitting the internal vibrations of $\mathrm{H}_{2} \mathrm{O}$, based on their local symmetry, taking into account the change in its symmetry when entering the hydrate lattice. Phosphates of solid solution $\mathrm{Zn}_{3-x} \mathrm{Co}_{x}\left(\mathrm{PO}_{4}\right)_{2} \cdot 4 \mathrm{H}_{2} \mathrm{O} \quad(0<x \leq 1.00)$ are isostructuraly, according to [6], with $\mathrm{Zn}_{3} \mathrm{Co}\left(\mathrm{PO}_{4}\right)_{2} \cdot 4 \mathrm{H}_{2} \mathrm{O}$, and crystallized in the space group $D^{16}{ }_{2 h}(P n m a)$. For this space group there is such a set of the local regulations: $C_{1}(8), 2 C_{1}(4), C_{s}$ (4). On the basis of atom position determined when identifying $\mathrm{Zn}_{3} \mathrm{Co}\left(\mathrm{PO}_{4}\right)_{2} \cdot 4 \mathrm{H}_{2} \mathrm{O}$ [9], the water molecules in the phosphates $\mathrm{Zn}_{3-x} \mathrm{Co}_{x}\left(\mathrm{PO}_{4}\right)_{2} \cdot 4 \mathrm{H}_{2} \mathrm{O}$ occupy $C_{s}$ and $C_{1}$ sites. In the case of local symmetry $C_{s}$ in the IR spectra three vibrations $v_{1}\left(A^{1}\right)$, $\mathrm{v}_{2}\left(A^{1}\right), \mathrm{v}_{3}\left(A^{\mathrm{II}}\right)$ at $C_{1}-\mathrm{v}_{1}(A), \mathrm{v}_{2}(A), \mathrm{v}_{3}(A)$ are active. That is, the two bands must correspond to every kind of water molecules in stretching frequency range, and the one band - in bending frequency range. This set of absorption bands is observed in the IR spectra of the solid phosphate solution at the low temperatures and in the deuterium analogue spectrum it is observed even at the room temperature (Table 1 ).

These data suggest the presence of $\mathrm{Zn}_{3-x} \mathrm{Co}_{x}\left(\mathrm{PO}_{4}\right)_{2} \cdot 4 \mathrm{H}_{2} \mathrm{O}$ in the structure of two types of non-equivalent water molecules of 
Table 1. Wave number $\left(\mathrm{cm}^{-1}\right)$ peaks of absorption bands in IR spectra of $\mathrm{Zn}_{3-x} \mathrm{Co}_{x}\left(\mathrm{PO}_{4}\right)_{2} \cdot 4 \mathrm{H}_{2} \mathrm{O}$ $(0<x \leq 1.00)$

\begin{tabular}{|c|c|c|c|c|}
\hline \multicolumn{2}{|c|}{$\mathrm{Zn}_{2} \mathrm{Co}\left(\mathrm{PO}_{4}\right)_{2} \cdot 4 \mathrm{H}_{2} \mathrm{O}$} & \multicolumn{2}{|c|}{$\mathrm{Zn}_{2} \mathrm{Co}\left(\mathrm{PO}_{4}\right)_{2} \cdot 4 \mathrm{D}_{2} \mathrm{O}$} & \multirow[t]{2}{*}{ Attribution } \\
\hline $20^{\circ} \mathrm{C}$ & $-190^{\circ} \mathrm{C}$ & $20^{\circ} \mathrm{C}$ & $-190^{\circ} \mathrm{C}$ & \\
\hline $\begin{array}{c}3500 \mathrm{~s} . \\
- \\
- \\
3240 \text { s.br. } \\
- \\
-\end{array}$ & $\begin{array}{c}3500 \mathrm{~s} . \\
- \\
3345 \mathrm{~s} . \\
3230 \mathrm{~s} . \\
- \\
3095 \mathrm{~s} .\end{array}$ & $\begin{array}{c}3500 \mathrm{sh} . \\
2580 \mathrm{~s} . \\
2480 \mathrm{sh} . \\
3230 \mathrm{sh} . \\
2400 \mathrm{~s} . \\
2280 \mathrm{~s} .\end{array}$ & $\begin{array}{c}3500 \mathrm{sh} . \\
2580 \mathrm{~s} . \\
2480 \mathrm{sh} . \\
3230 \mathrm{sh} . \\
2400 \mathrm{~s} . \\
2280 \mathrm{~s} .\end{array}$ & $v(\mathrm{OH})(\mathrm{OD})$ \\
\hline $\begin{array}{c}- \\
1630 \mathrm{~s} .\end{array}$ & $\begin{array}{l}1635 \mathrm{~s} . \\
1630 \mathrm{~s} .\end{array}$ & $\begin{array}{c}- \\
1225 \text { calculated }\end{array}$ & $\begin{array}{l}- \\
-\end{array}$ & $\delta\left(\mathrm{H}_{2} \mathrm{O}\right)$ \\
\hline $\begin{array}{c}- \\
1095 \mathrm{~s} . \\
1060 \mathrm{sh} . \\
1015 \mathrm{sh} . \\
1000 \mathrm{~s} .\end{array}$ & $\begin{array}{l}1130 \mathrm{sh} \\
1095 \mathrm{~s} . \\
1060 \mathrm{~s} . \\
1020 \mathrm{~s} . \\
1005 \mathrm{~s} .\end{array}$ & $\begin{array}{c}1130 \mathrm{sh} . \\
1095 \mathrm{~s} . \\
1060 \mathrm{sh} . \\
1015 \mathrm{sh} . \\
1000 \mathrm{~s} .\end{array}$ & $\begin{array}{l}1130 \mathrm{sh} . \\
1095 \mathrm{~s} . \\
1060 \mathrm{~s} . \\
1020 \mathrm{~s} . \\
1005 \mathrm{~s} .\end{array}$ & $v_{3}\left(\mathrm{PO}_{4}\right)$ \\
\hline $\begin{array}{c}940 \mathrm{~s} . \\
- \\
\end{array}$ & $\begin{array}{l}940 \mathrm{~s} . \\
930 \mathrm{sh} .\end{array}$ & $\begin{array}{l}940 \mathrm{~s} . \\
930 \mathrm{sh} .\end{array}$ & $\begin{array}{c}940 \mathrm{~s} . \\
930 \mathrm{sh} .\end{array}$ & $v_{1}\left(\mathrm{PO}_{4}\right)$ \\
\hline $\begin{array}{c}- \\
750 \mathrm{sh} . \\
625 \mathrm{~s} .\end{array}$ & $\begin{array}{c}860 \mathrm{sh} . \\
780 \mathrm{av} . \\
630 \mathrm{~s} .\end{array}$ & $\begin{array}{c}- \\
580 \text { av. } \\
480 \text { av. }\end{array}$ & $\begin{array}{c}860 \mathrm{sh} . \\
580 \mathrm{av} . \\
480 \mathrm{~s} .\end{array}$ & $\rho(\mathrm{OH})(\mathrm{OD})$ \\
\hline $\begin{array}{l}620 \mathrm{~s} . \\
570 \mathrm{w} .\end{array}$ & $\begin{array}{l}620 \mathrm{~s} . \\
580 \mathrm{~s} .\end{array}$ & $\begin{array}{l}630 \text { av. } \\
570 \text { av. }\end{array}$ & $\begin{array}{l}630 \mathrm{w} . \\
570 \mathrm{av} .\end{array}$ & $v_{4}\left(\mathrm{PO}_{4}\right)$ \\
\hline $\begin{array}{c}500 \mathrm{sh} . \\
- \\
420 \mathrm{w} . \\
-\end{array}$ & $\begin{array}{l}490 \mathrm{av} . \\
450 \mathrm{sh} . \\
420 \mathrm{~s} . \\
415 \mathrm{sh} .\end{array}$ & $\begin{array}{c}500 \mathrm{sh} . \\
- \\
- \\
-\end{array}$ & $\begin{array}{c}490 \text { av. } \\
- \\
- \\
-\end{array}$ & $v_{2}\left(\mathrm{PO}_{4}\right)$ \\
\hline
\end{tabular}

Comment: s. - strong, av. - average, w. - weak, sh. — shoulder, br. — broad.

the low symmetry. Their tough fixing, both in Oxygen and in Hydrogen, indicates absorption bands of libration vibrations of water molecules in the spectrum. In the spectrum of $\mathrm{Zn}_{2} \mathrm{Co}\left(\mathrm{PO}_{4}\right)_{2} \cdot 4 \mathrm{H}_{2} \mathrm{O}$ they include shoulder at $750 \mathrm{~cm}^{-1}$ and peak at $625 \mathrm{~cm}^{-1}$, in deuterium analogue -580 and $480 \mathrm{~cm}^{-1}$, respectively (isotope replacement ratio 1.33 ).

Character of configuration of the absorption bands $v(\mathrm{OH})$, their shape (expansion and low frequency vibrations as compared to free water molecules $-3700 \mathrm{~cm}^{-1}$ ) indicates the existence of hydrogen bonds in the structure $\mathrm{Zn}_{3-x} \mathrm{Co}_{x}\left(\mathrm{PO}_{4}\right)_{2} \cdot 4 \mathrm{H}_{2} \mathrm{O}$. The difference in the values of the maxima bands $v(\mathrm{OH})$ reaches $254-260 \mathrm{~cm}^{-1}$ (Table 2). The vibrations allow us to consider each of two $\mathrm{OH}$-groups of the same water molecules as independent each from other, and to believe that they take part in formation of the different strength and directivity $\mathrm{H}$-bonds. In addition to that, $\mathrm{HOH}$ angle in the molecules of water does not depend on the com- position of phosphates, as indicates almost identical values of $\delta\left(\mathrm{H}_{2} \mathrm{O}\right)$. The absence of significant changes in $\delta\left(\mathrm{H}_{2} \mathrm{O}\right)$ in the spectra obtained at $-190^{\circ} \mathrm{C}$, and increased value of their frequency $\left(1630 \mathrm{~cm}^{-1}\right.$ compared to the vibrations frequency of free water molecules $-1595 \mathrm{~cm}^{-1}$ ) indicates the existence of the rigid system of hydrogen bonds in the structure of $\mathrm{Zn}_{3-x} \mathrm{Co}_{x}\left(\mathrm{PO}_{4}\right)_{2} \cdot 4 \mathrm{H}_{2} \mathrm{O}$. Some $\mathrm{OH}$-groups (which corresponds to the maximum absorption of vibrations at the frequency range of $3270-3240 \mathrm{~cm}^{-1}$ ) are involved in formation of the rather strong hydrogen bonds with phosphate anion $\left[\mathrm{Me}^{2+}-\mathrm{OH}_{\mathrm{H}} . \mathrm{OPO}_{3}\right]$. Other OH-groups (absorption at the range of $3520-3500 \mathrm{~cm}^{-1}$ ) are connected relatively weak within interactions between $\mathrm{OH}$ groups of different water molecules $-\left[\mathrm{Me}^{2+}-\mathrm{OH}_{2} \ldots \mathrm{OH}_{2}\right]$.

Analysis of the IR spectra of $\mathrm{Zn}_{3-x} \mathrm{Co}_{x}\left(\mathrm{PO}_{4}\right)_{2} \cdot 4 \mathrm{H}_{2} \mathrm{O}$ with different content of zinc and cobalt has shown that with increases of the cobalt content in the coordi- 
Table 2. Wave number $\left(\mathrm{cm}^{-1}\right)$ peaks of absorption bands $\mathrm{v}(\mathrm{OH})$ in IR spectra $\mathrm{Zn}_{3-x} \mathrm{Co}_{x}\left(\mathrm{PO}_{4}\right)_{2} \cdot 4 \mathrm{H}_{2} \mathrm{O}$ $(0<x \leq 1.00)$ and characterization of $\mathrm{H}$-bonds

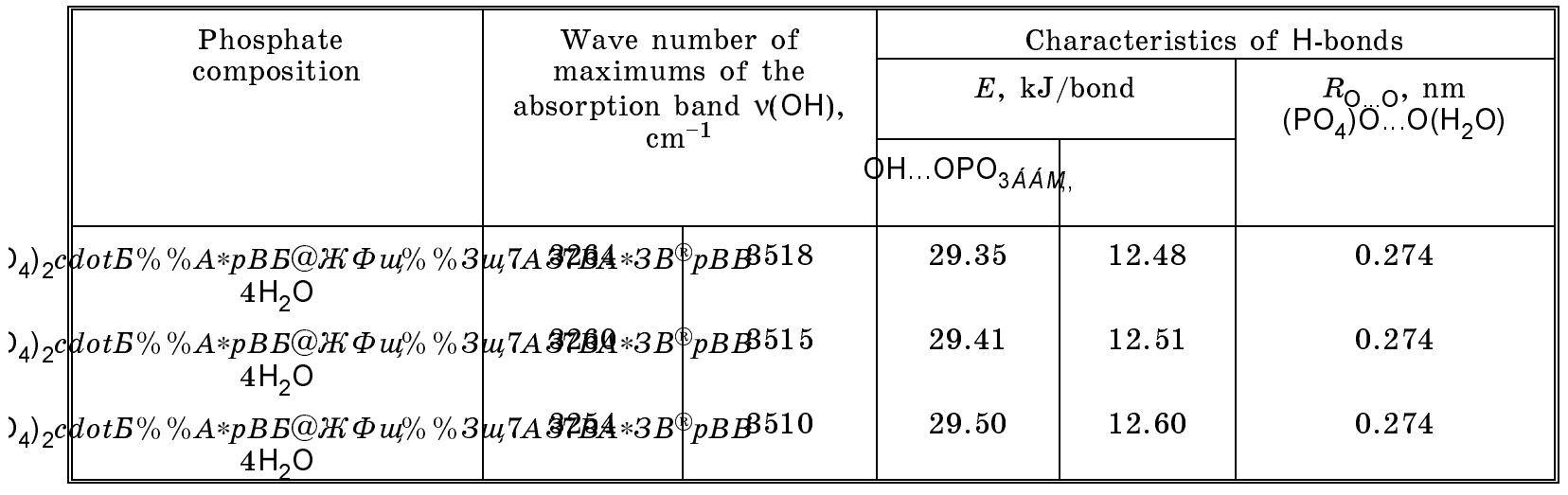

nating polyhedron there is natural shift of the maxima of the absorption bands $v(\mathrm{OH})$ to the low-frequency region, as both in $\mathrm{M}^{2+}-$ $\mathrm{OH}_{2} \ldots \mathrm{OPO}_{3}$, and $\mathrm{M}^{2+}-\mathrm{OH}_{2} \ldots \mathrm{OH}_{2}$ groups. It is clearly registered in the IR spectra of the samples deposited on $\mathrm{CaF}_{2}$ (Fig. 1). The energy of hydrogen bonds is assessed according to [3] by this shift, increases at the transition from $\mathrm{Zn}_{2.8} \mathrm{Co}_{0.2}\left(\mathrm{PO}_{4}\right)_{2} \cdot 4 \mathrm{H}_{2} \mathrm{O}$ to $\mathrm{Zn}_{2} \mathrm{Co}\left(\mathrm{PO}_{4}\right)_{2} \cdot 4 \mathrm{H}_{2} \mathrm{O}$ (Table 2).

The given conclusion agrees completely with the thermal and analytical researches on phosphates of the solid solution $\mathrm{Zn}_{3-x} \mathrm{Co}_{x}\left(\mathrm{PO}_{4}\right)_{2} \cdot 4 \mathrm{H}_{2} \mathrm{O}$, which state that the highest thermal stability has phosphate, energy of $\mathrm{H}$-bonds in the structure of which has the greatest value $\mathrm{Zn}_{2} \mathrm{Co}\left(\mathrm{PO}_{4}\right)_{2} \cdot 4 \mathrm{H}_{2} \mathrm{O}$. The temperature of the beginning of crystalline hydrate water removal increases with growth of the energy of $\mathrm{H}$-bonds realized in the structure: from $80^{\circ} \mathrm{C}$ for $\mathrm{Zn}_{2.8} \mathrm{CO}_{0.2}\left(\mathrm{PO}_{4}\right)_{2} \cdot 4 \mathrm{H}_{2} \mathrm{O}$, up to $90^{\circ} \mathrm{C}$ for $\mathrm{Zn}_{2.5} \mathrm{Co}_{0.5}\left(\mathrm{PO}_{4}\right)_{2} \cdot 4 \mathrm{H}_{2} \mathrm{O}$, and $105^{\circ} \mathrm{C}$ for $\mathrm{Zn}_{2} \mathrm{Co}\left(\mathrm{PO}_{4}\right)_{2} \cdot 4 \mathrm{H}_{2} \mathrm{O}$ (Table 3).

The phosphates thermal stability can be significantly improved by using quasiisotermic heat treatment regime, in which the partial pressure of water vapor over the sample is close to the thermodynamic equilibrium one. Under these conditions, the weight loss for $\mathrm{Zn}_{2} \mathrm{Co}\left(\mathrm{PO}_{4}\right)_{2} \cdot 4 \mathrm{H}_{2} \mathrm{O}$, for example, starts when heating up to $180^{\circ} \mathrm{C}$, for $\mathrm{Zn}_{2.5} \mathrm{Co}_{0.5}\left(\mathrm{PO}_{4}\right)_{2} \cdot 4 \mathrm{H}_{2} \mathrm{O}-$ up to $160^{\circ} \mathrm{C}$ (Fig. 2).

Dehydration of tetrahydrate $\mathrm{Zn}_{2} \mathrm{Co}\left(\mathrm{PO}_{4}\right)_{2} \cdot 4 \mathrm{H}_{2} \mathrm{O}$ is implemented in two stages, characterized by deep endothermic effects on DTA curves and DTG at the range of $105-240^{\circ} \mathrm{C}$ and $265-340^{\circ} \mathrm{C}$ (the first and the second stages of dehydration, respectively). The mass loss in each effect

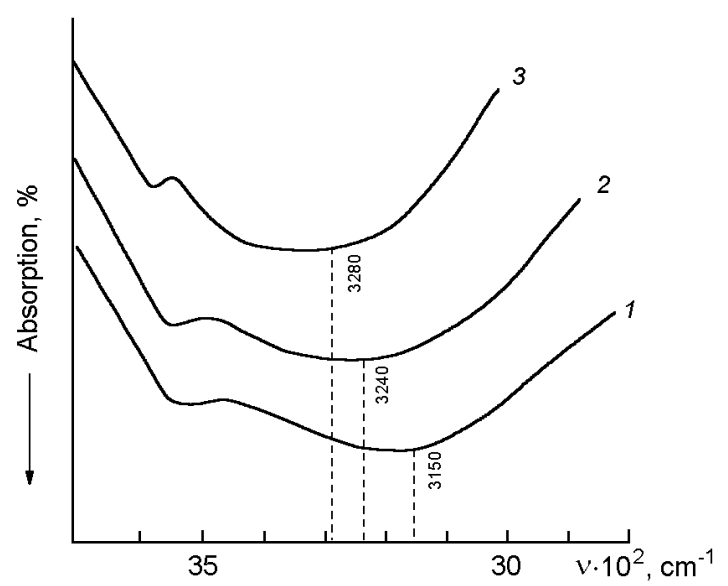

Fig. 1. IR spectra of $\mathrm{Zn}_{2} \mathrm{Co}\left(\mathrm{PO}_{4}\right)_{2} \cdot 4 \mathrm{H}_{2} \mathrm{O}$ (1), $\mathrm{Zn}_{2.5} \mathrm{Co}_{0.5}\left(\mathrm{PO}_{4}\right)_{2} \cdot 4 \mathrm{H}_{2} \mathrm{O}(2), \mathrm{Zn}_{2.8} \mathrm{Co}_{0.2}\left(\mathrm{PO}_{4}\right)_{2} \cdot 4 \mathrm{H}_{2} \mathrm{O}$ (3) deposited on $\mathrm{CaF}_{2}$.

region corresponds to removing of two moles of water and, mostly, ends at $340^{\circ} \mathrm{C}$.

The product formed at the first stage of dehydration is identified as dehydrate of composition $\mathrm{Zn}_{2} \mathrm{Co}\left(\mathrm{PO}_{4}\right)_{2} \cdot 2 \mathrm{H}_{2} \mathrm{O}$. Its X-ray and IR-spectroscopic characteristics correspond to known for isostructural $\mathrm{Zn}_{3}\left(\mathrm{PO}_{4}\right)_{2} \cdot 2 \mathrm{H}_{2} \mathrm{O}$ [10]. The spectral pattern of $\mathrm{Zn}_{2} \mathrm{Co}\left(\mathrm{PO}_{4}\right)_{2} \cdot 2 \mathrm{H}_{2} \mathrm{O}$, obtained at $240^{\circ} \mathrm{C}$ $\left(\mathrm{Zn}_{2.5} \mathrm{Co}_{0.5}\left(\mathrm{PO}_{4}\right)_{2} \cdot 2 \mathrm{H}_{2} \mathrm{O}\right.$ at $\left.190^{\circ} \mathrm{C}\right)$ changes compared to the initial tetrahydrate at all frequency ranges (Fig. 3). The absorption band $v(\mathrm{OH})$ is asymmetrical with the maximum at $3400 \mathrm{~cm}^{-1}$ and clearly contemplated shoulder $3180 \mathrm{~cm}^{-1}$. In the characteristic frequencies of anions $\mathrm{PO}_{4}{ }^{3-}$ vibrations the narrowing of spectral interval absorption occurs and the maxima 1060 and $1015 \mathrm{~cm}^{-1}$ disappear. This indicates restructuring of the bonds in the structure and, in particular, the reduction of the correlation field caused by the interaction of $\mathrm{PO}_{4}$-tetrahe- 
Table 3. Dependences of thermal properties of solid solution phosphates $\mathrm{Zn}_{3-x} \mathrm{Co}_{x}\left(\mathrm{PO}_{4}\right)_{2} \cdot 4 \mathrm{H}_{2} \mathrm{O}$ $(0<x \leq 1.00)$ on their composition (heating rate 2.5 degree/min)

\begin{tabular}{|c|c|c|c|c|c|c|}
\hline \multirow[t]{2}{*}{ Phosphate composition } & \multicolumn{3}{|c|}{ The first stage of dehydration, ${ }^{\circ} \mathrm{C}$} & \multicolumn{3}{|c|}{ The second stage of dehydration, ${ }^{\circ} \mathrm{C}$} \\
\hline & Start & Finish & $\begin{array}{c}\text { Rate } \\
\text { maximum }\end{array}$ & Start & Finish & $\begin{array}{c}\text { Rate } \\
\text { maximum }\end{array}$ \\
\hline 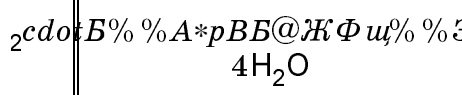 & $3 u, 7 A B D A$ & $p B 1 B 5$ & 145 & 200 & 300 & 220 \\
\hline 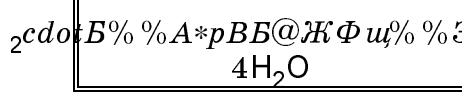 & $\$ щ 7 A 9 \nabla B$ & $p B 190$ & 175 & 225 & 320 & 245 \\
\hline
\end{tabular}

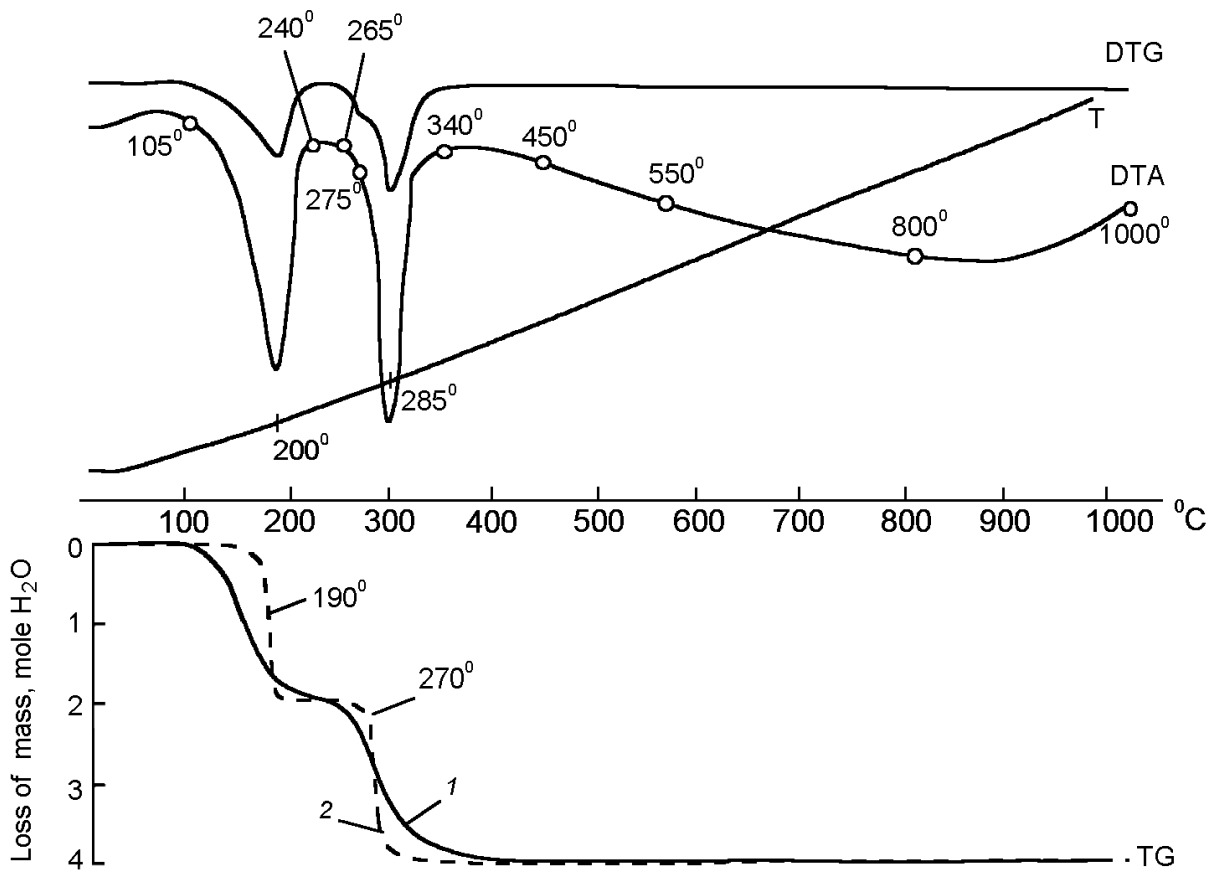

Fig. 2. Curves of differential thermal analysis of $\mathrm{Zn}_{2} \mathrm{Co}\left(\mathrm{PO}_{4}\right)_{2} \cdot 4 \mathrm{H}_{2} \mathrm{O}: 1$ - in dynamic (heating rate 2.5 degree/min), 2 - quasiisotermic heating regime, -o- _ place of sampling the sample for analysis.

dron together. As a result, splitting of the absorption bands is determined, mainly by the anion symmetry (effect of the static fields), which leads to decrease of the absorption bands number.

The spectrum of the sample obtained by $\mathrm{Zn}_{2} \mathrm{Co}\left(\mathrm{PO}_{4}\right)_{2} \cdot 4 \mathrm{H}_{2} \mathrm{O}$ heating up to $265^{\circ} \mathrm{C}$ is quite similar to the previous one (Fig. 3 ). Two absorption maxima recorded at $20^{\circ} \mathrm{C}$ in the $\mathrm{v}(\mathrm{OH})$ at $-190^{\circ} \mathrm{C}$ are not separated. This shows that in the range of $105-240^{\circ} \mathrm{C}$ temperature at least two tightly bound water molecules remove, and this is accompanied by the restructuring of $\mathrm{H}$-bonds in the crystalline structure. Dihydrate $\mathrm{Zn}_{2} \mathrm{Co}\left(\mathrm{PO}_{4}\right)_{2} \cdot 2 \mathrm{H}_{2} \mathrm{O}$, which is formed, is stable when heated at the range of $240-265^{\circ} \mathrm{C}$. Calculation of the energy of hydrogen bonds, that are formed in its structure indicates that two water molecules remaining are involved in formation of the system of the strong hydrogen bonds (about 20-35 kJ/mole), that are different from $\mathrm{H}$-bonds in the structure of the initial tetrahydrate.

The subsequent heat treatment of $\mathrm{Zn}_{2} \mathrm{Co}\left(\mathrm{PO}_{4}\right)_{2} \cdot 2 \mathrm{H}_{2} \mathrm{O}$ dihydrate in the range of $265-340^{\circ} \mathrm{C}$ (the second stage of dehydration) is registered on the DTA and DTG with endothermic effect, that has two nearly overlapping endothermic effects with the maximum speeds processes at 275 and $285^{\circ} \mathrm{C}$. The total sample mass loss in this effect corresponds to removing of two water molecules. The dehydration of $\mathrm{Zn}_{2} \mathrm{Co}\left(\mathrm{PO}_{4}\right)_{2} \cdot 2 \mathrm{H}_{2} \mathrm{O}$ in the quasiisotermic regime is also described by legible step of the mass loss at $270^{\circ} \mathrm{C}$, that defines the joint removing of two $\mathrm{H}_{2} \mathrm{O}$ moles (Fig. 2). 


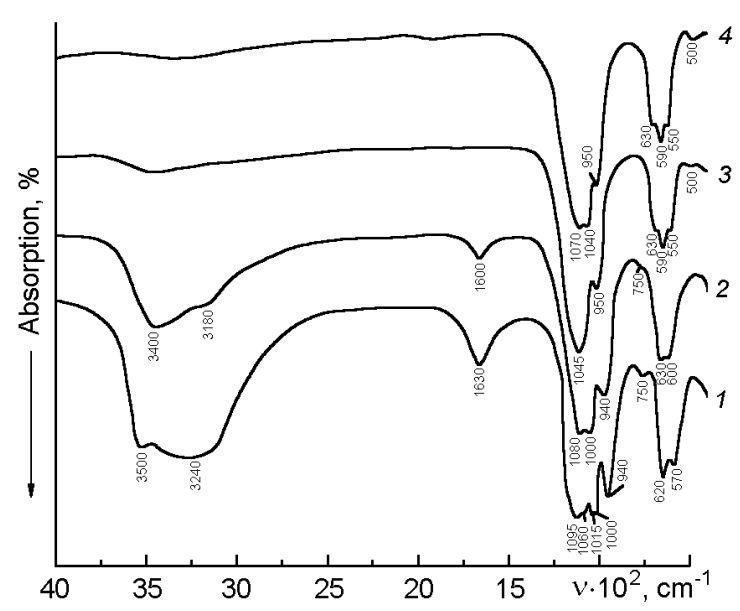

Fig. 3. IR spectra of $\mathrm{Zn}_{2.0} \mathrm{Co}\left(\mathrm{PO}_{4}\right)_{2} \cdot 4 \mathrm{H}_{2} \mathrm{O}$ (1) and the products of its thermal dehydration obtained at $105^{\circ} \mathrm{C}$ (1) $240-265^{\circ} \mathrm{C}$ (2), 340$450^{\circ} \mathrm{C}(3), 900^{\circ} \mathrm{C}(4)$.

Explanation of the established fact follows from consideration of the structural features of $\mathrm{Zn}_{3}\left(\mathrm{PO}_{4}\right)_{2} \cdot 4 \mathrm{H}_{2} \mathrm{O}$ [9] and the solid solution on its bases with composition $\mathrm{Zn}_{3-x} \mathrm{Co}_{x}\left(\mathrm{PO}_{4}\right)_{2} \cdot 4 \mathrm{H}_{2} \mathrm{O}$ [6]. In the structure of the tetrahydrates there are two crystal and graphical nonequivalent types of coordinational bounds of water molecules. Interatomic distances between the cation and Oxygen in the water molecules in the coordination polyhedron, considering the participation of $\mathrm{OH}$-groups of the water molecules in formation of the hydrogen bonds formed in the structure, are different. They are $0.2099 \mathrm{~nm}\left(\mathrm{H}_{2} \mathrm{O}-\mathrm{I}\right)$ and $0.2116 \mathrm{~nm}\left(\mathrm{H}_{2} \mathrm{O}\right.$ - II) for the water molecules, that occupy opposite vertices in the octahedron (transposition) and $0.2159 \mathrm{~nm}$ for molecules $\left(\mathrm{H}_{2} \mathrm{O}\right.$ - III) located on the sharing edges of the octahedra (cis-position). Lengths of the ties between the two water molecules $\left(\mathrm{H}_{2} \mathrm{O}-\right.$ III) with cation are 2-3\% bigger, than for $\mathrm{H}_{2} \mathrm{O}-\mathrm{I}$ and $\mathrm{H}_{2} \mathrm{O}-$ II. This allows us to assume the fact that their separate pairs remove during the heating. And, above all, the most weakly bound to the cation water will be removed, that is two molecules of $\mathrm{H}_{2} \mathrm{O}-$ III. And this is observed at the first stage of dehydration of $\mathrm{Zn}_{2} \mathrm{Co}\left(\mathrm{PO}_{4}\right)_{2} \cdot 4 \mathrm{H}_{2} \mathrm{O}$ in the range of $105-240^{\circ} \mathrm{C}$.

The length of cation ties with molecules of $\mathrm{H}_{2} \mathrm{O}-\mathrm{I}$ and $\mathrm{H}_{2} \mathrm{O}$ - II differs a little (at $0.78 \%$ ). In addition, the second stage of the dehydration is characterized by the dehydrate dehydration, the structure of which due to redistribution of the $\mathrm{H}$-bonds after removal of the first two mole of $\mathrm{H}_{2} \mathrm{O}$, values of the bond lengths cation with $\mathrm{H}_{2} \mathrm{O}-$
I and $\mathrm{H}_{2} \mathrm{O}$ - II changed, and considering the IR spectra data became closer. This complicates the removal of each of the separate water molecules remaining and leads to almost complete overlaying of two endothermic effects, that characterize these processes in the second stage of dehydration of $\mathrm{Zn}_{2} \mathrm{Co}\left(\mathrm{PO}_{4}\right)_{2} \cdot 4 \mathrm{H}_{2} \mathrm{O}$ (Fig. 2).

The mass loss in the tetrahydrate is almost finished in the case of heating above $300-340^{\circ} \mathrm{C}$ (Table 3 ). The slight changes associated with the removal of the final amount of water are observed when the sample is heated to $400-450^{\circ} \mathrm{C}$. When further raising the temperature to $900^{\circ} \mathrm{C}$, the mass loss on TG curve is not registered (Fig. 2).

In the IR spectra of the thermal transformations, that take place at the second stage of dehydration of $\mathrm{Zn}_{2} \mathrm{Co}\left(\mathrm{PO}_{4}\right)_{2} \cdot 4 \mathrm{H}_{2} \mathrm{O}$ $\left(265-340^{\circ} \mathrm{C}\right)$, it is observed the significant change in the whole spectral range (Fig. 3). Absorption bands that characterize the vibrations of water molecules are almost absent. Configuration of the absorption bands in the anion vibrations changes significantly. The spectral range of the fixed bands narrows, and appearance of the new intense band $\left(550 \mathrm{~cm}^{-1}\right)$, referring to three degenerate antisymmetric deformational vibrations, indicates significant degree of deformation of the phosphate tetrahydra, whose interaction among themselves weakens due to absence of the hydrogen bonds (the correlation effect field is at minimum).

The IR spectrum of the dehydrated $\mathrm{Zn}_{2} \mathrm{Co}\left(\mathrm{PO}_{4}\right)_{2} \cdot 4 \mathrm{H}_{2} \mathrm{O}$ at $900^{\circ} \mathrm{C}$ is similar to the spectrum of the sample obtained by heating up to $340^{\circ} \mathrm{C}$. Strong absorption bands splitting and increasing of their intensity is the evidence of improved structure of the dehydrated phosphate. These data complement the results of $\mathrm{X}$-ray analysis of the products of dehydration of $\mathrm{Zn}_{2} \mathrm{Co}\left(\mathrm{PO}_{4}\right)_{2} \cdot 4 \mathrm{H}_{2} \mathrm{O}$, under which the completely dehydrated phosphate is identified as $\gamma-\mathrm{Zn}_{2} \mathrm{Co}\left(\mathrm{PO}_{4}\right)_{2}$ (monoclinic system, sp.gr. $\left.P 2_{1} / n\right)$. It is stable when heated at the range of $340-900^{\circ} \mathrm{C}$.

Thus, the sequence of the thermal solid phase transformations, that accompany the dehydration of phosphate of $\mathrm{Zn}_{2} \mathrm{Co}\left(\mathrm{PO}_{4}\right)_{2} \cdot 4 \mathrm{H}_{2} \mathrm{O}$ composition can be described as follows:

$$
\begin{gathered}
\mathrm{Zn}_{2} \mathrm{CoPo}_{42} \cdot 4 \mathrm{H}_{2} \mathrm{O} \frac{105-240{ }^{\circ} \mathrm{C}}{-2 \mathrm{H}_{2} \mathrm{O}} \\
\rightarrow \mathrm{Zn}_{2} \mathrm{Co}^{1}\left(\mathrm{PO}_{4}\right)_{2} \cdot 2 \mathrm{H}_{2} \mathrm{O} \underset{265-340{ }^{\circ} \mathrm{C}}{-2 \mathrm{H}_{2} \mathrm{O}} \mathrm{\gamma}-\mathrm{Zn} \mathrm{n}_{2} \mathrm{Co}\left(\mathrm{PO}_{4}\right)_{2} .
\end{gathered}
$$

Functional materials, 22, 4, 2015 
These correspond to the heat treatment temperature ranges of $\mathrm{Zn}_{2} \mathrm{Co}\left(\mathrm{PO}_{4}\right)_{2} \cdot 4 \mathrm{H}_{2} \mathrm{O}$ in dynamic conditions with the heating rate of 2.5 degree/min. Changing of the heating rate leads to shift in the temperature ranges of formation and thermal stability of the products of partial and complete dehydration. So when the heating rate reaches 0.6 degree $/ \min \mathrm{Zn}_{2} \mathrm{Co}\left(\mathrm{PO}_{4}\right)_{2} \cdot 4 \mathrm{H}_{2} \mathrm{O}$ is stable up to $80^{\circ} \mathrm{C}$. In the range of $80-210^{\circ} \mathrm{C}$ (the first stage of water removal) formation of phosphate of lower hydration $\mathrm{Zn}_{2} \mathrm{Co}\left(\mathrm{PO}_{4}\right)_{2} \cdot 4 \mathrm{H}_{2} \mathrm{O}$ takes place. Received at $210^{\circ} \mathrm{C}$ dihydrate is stable even in the range of $210-235^{\circ} \mathrm{C}$, but now it loses two water molecules to form the completely dehydrated $\gamma-\mathrm{Zn}_{2} \mathrm{Co}\left(\mathrm{PO}_{4}\right)_{2}$ when heated up to $310^{\circ} \mathrm{C}$. When heating rate is 10.0 degree/min formation of $\mathrm{Zn}_{2} \mathrm{Co}\left(\mathrm{PO}_{4}\right)_{2} \cdot 2 \mathrm{H}_{2} \mathrm{O}$ and $\gamma-\mathrm{Zn}_{2} \mathrm{Co}\left(\mathrm{PO}_{4}\right)_{2}$ is recorded at $120-255^{\circ} \mathrm{C}$ and $280-370^{\circ} \mathrm{C}$, respectively. The common process patterns remain.

This scheme of dehydration of $\mathrm{Zn}_{2} \mathrm{Co}\left(\mathrm{PO}_{4}\right)_{2} \cdot 4 \mathrm{H}_{2} \mathrm{O}$ is the same for phosphates of the solid solution of $\mathrm{Zn}_{3-x} \mathrm{Co}_{x}\left(\mathrm{PO}_{4}\right)_{2} \cdot 4 \mathrm{H}_{2} \mathrm{O} \quad(0<x \leq 1.00)$ of different composition. The cation nature affects on the temperature ranges of resistance of the both initial crystalline hydrates and products of their partial and full dehydration. It was established, that the maximum for the phosphates of the solid solution $\mathrm{Zn}_{3-x} \mathrm{Co}_{x}\left(\mathrm{PO}_{4}\right)_{2} \cdot 4 \mathrm{H}_{2} \mathrm{O} \quad(0<x \leq 1.00)$ with the larger content of cobalt is caused by the energy state of water molecules in their crystal structures.

\section{Conclusions}

In the structure of phosphate solid solution with composition $\mathrm{Zn}_{3-x} \mathrm{Co}_{x}\left(\mathrm{PO}_{4}\right)_{2} \cdot 4 \mathrm{H}_{2} \mathrm{O}$ $(0<x \leq 1.00)$ there are two types of nonequivalent water molecules, $\mathrm{OH}$-groups of which form the rigid system of different strength and directivity of hydrogen bonds. The energy of the $\mathrm{H}$-bonds and the asymmetry of related water molecules increases with increasing of cobalt content in the composition of $\mathrm{Zn}_{3-x} \mathrm{Co}_{x}\left(\mathrm{PO}_{4}\right)_{2} \cdot 4 \mathrm{H}_{2} \mathrm{O}$.

Thermal stability of the crystalline hydrates of the solid solution of $\mathrm{Zn}_{3-x} \mathrm{Co}_{x}\left(\mathrm{PO}_{4}\right)_{2} \cdot 4 \mathrm{H}_{2} \mathrm{O}$ $(0<x \leq 1.00)$ correlates with the energy state of water molecules in their structure and is at the maximum for phosphate of the composition $\mathrm{Zn}_{2} \mathrm{Co}\left(\mathrm{PO}_{4}\right)_{2} \cdot 4 \mathrm{H}_{2} \mathrm{O}$. Temperature range of formation and thermal stability of the products of partial and complete dehydration is also at $30-40^{\circ} \mathrm{C}$ higher, than for the phosphates with the smaller cobalt content.

\section{References}

1. T.Kanazawa, Inorganic Phosphate Materiales, Elsevier, New York (1989).

2. L.N.Shchegrov, Phosphaty Dvuhvalentnyh Metallov, Naukova Dumka, Kiev (1987) [in Russian].

3. V.N.Makatun, Chemistry of Inorganic Hydrates, Nauka i Tehnika, Moscow (1985) [in Russian].

4. L.Robertson, Etude de Pigments Thermochromes Autour du Cobalt II. Material Chemistry, Universite Sciences et Technologies, Bordeaux I (2010).

5. W.Y.Wu, X.Q.Liang, Y.Z.Li, Acta Cryst., E61, 105 (2005).

6. UA Patent 84621, (2013).

7. N.M.Antraptseva, L.N.Shchegrov, J.Inorg. Chem., 28, 2818 (1983).

8. N.M.Antraptseva, N.V.Tkachova, J.Appl. Chem., 82, 1153 (2009).

9. A.Whitaker, Acta Crystallogr., 31, 2026 (1975).

10. V.V.Pechkovskiy, R.Y.Melnikova, E.D.Dzyuba et al., Atlas of the Infrared Spectra of Phosphates, Orthophosphate, Nauka, Moscow (1981) [in Russian]. 